ВІСНИК

ОДЕСЬКОГО НАЦІОНАЛЬНОГО

МОРСЬКОГО УНІВЕРСИТЕТУ

№ 2 (59), 2019
HERALD

OF THE ODESSA NATIONAL

MARITIME UNIVERSITY № 2 (59), 2019

УДК 629.5.01

DOI 10.33082/2226-1915-2--2019-11-40

\title{
КОНЦЕПЦИЯ МНОГОФУНКЦИОНАЛЬНОГО ЛЕДОКОЛА - СУДНА ОБЕСПЕЧЕНИЯ МОЩНОСТЬЮ 22 МВТ
}

\author{
Г.В. Егоров \\ д.т.н., профессор, генеральный директор \\ Н.В. Автутов \\ главный конструктор, директор по перспективному розвитию
}

Морское инженерное бюро, г. Одесса

Аннотация. Небходимость строительства многофункциональных ледокольных судов обеспечения для круглогодичной работы в районе Обской губы. Обоснованы принятые при проектировании и постройки технические решения одного из самых мощных в мире дизель-электрических ледоколов проекта IBSV01 мощностью 22 MBm с ледокольным классом Icebreaker8. Особое внимание уделено обводам и пропульсивному комплексу. Приведены результаты испытаний, которые в полной мере удовлетворяют требованиям Заказчика как по ходовым, так и по функииональным качествам, показывают высокую маневренность и ледопроходимость.

Ключевые слова: Северный морской путь, ледокол, судно обеспечения, проектирование, обводы, строительство, конщепция, испьтания, безопасность, инновачия.

\section{УДК 629.5.01}

DOI 10.33082/2226-1915-2--2019-11-40

\section{КОНЦЕПЦІ БАГАТОФУНКЦІОНАЛЬНОГО КРИГОЛАМА - СУДНА ЗАБЕЗПЕЧЕННЯ ПОТУЖНІСТЮ 22 МВТ}

\author{
Г.В. Сгоров \\ д.т.н., професор, генеральний директор \\ М.В. Автутов \\ головний конструктор, директор по перспективному розвитку \\ Морське інженерне бюро, м. Одеса
}

Анотація. Показано необхідність будівництва багатофункиіональних криголамів-суден забезпечення для иілорічної роботи в районі Обської губи. Обтрунтовано прийняті при проектуванні $і$ будівництві технічні рішення одного з найпотужніших в світі дизель-електричних криголамів проекту IBSV01 потужністю 22 МВт з криголамним класом Icebreaker8. Особливу увагу приділено обводам і пропульсивному комплексу. Наведено результати випробувань, які в повній мірі задовольняють вимогам Замовника як за ходовими, так $і$ за функиіональними якостями, показують високу маневреність і льодопрохідність.

(C) Егоров Г.В., Автутов Н.В., 2019 
ВІСНИК

ОДЕСЬКОГО НАЦІОНАЛЬНОГО

МОРСЬКОГО УНІВЕРСИТЕТУ

№ 2 (59), 2019
HERALD

OF THE ODESSA NATIONAL

MARITIME UNIVERSITY № 2 (59), 2019

Ключові слова: Північний морський илях, криголам, судно забезпечення, проектування, обводи, будівництво, концепція, випробування, безпека, інновачія.

UDC 629.5.01

DOI 10.33082/2226-1915-2-2019-11-40

\title{
CONCEPT OF 22 MW MULTIFUNCTIONAL ICEBREAKING - SUPPLY VESSELS
}

\author{
G.V. Yegorov \\ Doctor of Technical Sciences, Professor, General Director \\ N.V. Aututov \\ Chief designer, director of perspective development \\ Marine Engineering Bureau, Odessa
}

\begin{abstract}
Necessity of building of multifunctional icebreaking supply vessels for all-year work in Gulf of Ob area is shown. Main design and building stages of one of the most powerful $22 \mathrm{MW}$ diesel-electric icebreakers of IBSV01 project put in operation with high arctic class Icebreaker 8 are grounded. The special attention is paid to hull form and propulsive complex. Trial results which fully meet Customer requirements both on running and functional qualities have shown high maneuverability and icebreaking capability.
\end{abstract}

Keywords: Northern Sea Route, icebreaker, supply vessel, design, hull form, building, concept, trials, safety, innovation.

Введение. В 2018 году Выборгский судостроительный завод сдал в эксплуатацию два самых мощных в мире (из построенных) дизельных ледокола мощностью $22 \mathrm{MBт,} \mathrm{которые} \mathrm{могут} \mathrm{работать} \mathrm{в} \mathrm{сплошном} \mathrm{льду}$ толщиной 2 метра с 30 см снежным покровом.

При этом головное судно проекта IBSV01 «Александр Санников» (строительный номер 233, см. рисунок 1) было заложено в ноябре 2015 года, а сдано в июне 2018 года, а второе - «Андрей Вилькицкий» (строительный 234) - в декабре 2018 года.

Концептуальный проект судна Aker ARC 130A был выполнен Aker Arctic Technology, технический проект IBSV01 разработан Морским Инженерным Бюро.

Постановка проблемы. На Новопортовском нефтегазоконденсатном месторождении предполагается добывать до 8,5 млн. тонн в год низкосернистой нефти сорта Novy Port, превосходящей по чистоте Urals и Brent [3].

Вывоз этого сырья предполагался морским путем из Арктического терминала «Ворота Арктики», расположенного в акватории Обской губы в районе Мыса Каменный на полуострове Ямал. 


\section{Рис. 1. Судно проекта IBSV01 «Александр Санников». Автор фотографии Иван Бородулин}

От кромки льдов в Баренцевом или Карском морях до входа в Обскую губу грузовые суда идут под проводкой линейных атомных ледоколов, далее до порта Сабетта - атомные ледоколы с малой осадкой типа «Таймыр», которые также обновляют каналы в тяжелых льдах на акватории портов [2].

На следующем этапе движения грузовых судов для круглогодичного обеспечения безопасного подхода танкеров типа «Штурман Альбанов» к арктическому терминалу, швартовных операций, буксировки, защиты «Ворот Арктики» от ударных воздействий льда требуются специальные дизельные ледоколы - суда обеспечения с малой осадкой.

Целью статьи является обоснование принятых при проектировании и постройки технические решения одного из самых мощных в мире дизель-электрических ледоколов проекта IBSV01, которые обеспечивают работу танкеров на терминале в Обской губе.

Изложение основного материала. Обская губа пресноводная, Максимальная глубина не превышает 28-30 м, но на большей части акватории составляет $10-15 \mathrm{M}$, отличается большим количеством отмелей (глубина падает до 10 метров). Амплитуда сгонных и нагонных колебаний уровня воды достигает 2 м и более. Ледовый период на акватории губы в среднем составляет около 9 месяцев в году (октябрь-июль). Годовая толщина ровного льда достигает наибольшего значения в мае до значений в 1,60-1,80 м, иногда до 2,40 м. Существует опасность зимних подвижек ледяного покрова, возникают значительные ледовые нагрузки на морские сооружения из-за высокой прочности пресноводного льда и смерзания ледяного покрова с сооружениями [2; 3; 4].

Для транспортировки используются арктические танкеры двойного действия (Double Acting Tanker - DAT) проекта 42K Arctic Shuttle Tanker дедвейтом 41500 тонн длиной 249 м и шириной 34 м типа «Штурман Альбанов» с ледовым классом ARC 7 и мощностью двух винторулевых колонок 22 МВт. Эти суда группы компаний «Совкомфлот» с осадкой 9,7 м могут самостоятельно преодолевать лед толщиной до 1,40 м (при движении вперед носом) и до 1,80 м (при движении кормой вперед).

Таким образом, перспективный концепт ледокола - судна обеспечения проекта IBSV01 должен был решить главные задачи:

- проводка танкеров проекта 42K Arctic Shuttle Tanker между портом Сабетта и районом мыса Каменный в Обской губе в ледовых условиях; 
ВІСНИК

ОДЕСЬКОГО НАЦІОНАЛЬНОГО

МОРСЬКОГО УНІВЕРСИТЕТУ № 2 (59), 2019
HERALD

OF THE ODESSA NATIONAL

MARITIME UNIVERSITY № 2 (59), 2019

- проводка танкеров проекта 42K Arctic Shuttle Tanker в грузовой район Арктического терминала в ледовых условиях;

- поддержка безопасности при причаливании и погрузке этих танкеров.

Кроме того, концепт IBSV01 должен был обеспечить:

- защиту Арктического терминала от ударных воздействий при образовании льда и движении ледяных полей;

- спасательные операции в районе Арктического терминала и оказание содействия судам в ледовых условиях и на открытой воде при волнении моря до 7 баллов по шкале Бофорта;

- поиск и спасение людей как на открытой воде при волнении до 5 баллов по шкале Бофорта, так и в ледовых условиях;

- проход во льдах в условиях малых глубин Обской губы;

- буксировку судов и морских плавучих сооружений в ледовых условиях и на чистой воде;

- доставку и транспортировку небольших партий палубного груза и эксплуатационного персонала на Арктический терминал;

- тушение пожаров на плавучих и береговых объектах, доступных для подхода с моря;

- поддержку подводно-технических водолазных работ на глубинах до 12 метров;

- дистанционное автоматизированное управление Арктическим терминалом;

- участие в операциях по ликвидации аварийных разливов нефти, как на открытой воде, так и в ледовых условиях в качестве транспортировщика оборудования и сборщика вод и нефтепродуктов, полученных в результате ликвидации разлива;

- временное размещение спасённых экипажей танкеров и других судов.

Как отмечается в $[1 ; 4 ; 5 ; 6]$, реализуемые в мире проекты судов специального назначения, оффшорных судов, а также ледоколов свидетельствует о тенденции в мировом судостроении насыщать такие суда в максимальной степени дополнительными функциями. Кроме того, наиболее перспективным направлением развития форм корпуса судов ледового плавания является дальнейшее совершенствование традиционных ледовых обводов. Они позволяют обеспечить гармоничное сочетание хороших ледовых качеств судна при эксплуатации как в сплошных, так и в природных битых льдах. Правильное определение основной и вспомогательных миссий многофункционального судна, выбор соответствующих прототипов, использование надежных статистических данных и приближенных зависимостей позволяют определить сочетание оптимальных характеристик формы корпуса и главных размерений на начальных стадиях проектирования. 
Определенные таким образом характеристики судна обеспечивают высокую ледопроходимость, хорошую ходкость в условиях чистой воды и удовлетворительную мореходность, что в целом предопределило успех выполнения миссии многофункционального судна ледового плавания.

Рассматриваемый концепт предназначался для круглогодичной эксплуатации в районе мыса Каменный Обской губы. Соответственно, выбор дизель-электрической силовой установки осуществляется из условия достаточности пропульсивной мощности для независимого прохода во льдах в ледовых условиях, превалирующих в районе эксплуатации. Поэтому концепт должен был работать в сплошном льду толщиной около 2,0 м и с 30-ти сантиметровым снежным покровом со скоростью 2 узла при движении вперед как носом, так и кормой.

Как судно обеспечения, которое будет работать с достаточно большими по своим габаритам танкерами в достаточно узком канале, концепт IBSV01 должен был иметь возможность хорошо маневрировать при работе в ледяной каше и сплошном льду, поэтому было выбрано оригинальное расположение полноповоротных винто-рулевых колонок - две в корме и одна в носу.

Таким образом, требовалось обосновать такие обводы, пропульсивную мощность и положение ВРК, которые бы обеспечили:

- отсутствие ограничения для работы в сплошном льду и сплочённом паковом льду толщиной до 2,0 м;

- возможность в сплошном льду и сплочённом паковом льду толщиной более 2,0 м движение малым ходом преимущественно носом вперед;

- возможность преодолевать торосы и толстый битый лед непрерывным ходом, используя эффект размывания винтами ВРК;

- работу набегами, используя массу и импульс концепта, только носом вперед со средней скоростью менее 5 узлов (но только не кормой вперед).

При этом судно должно было развивать скорость около 16 узлов на глубокой воде при 85 \% МДМ и ветре и волнении до 3 баллов по шкале Бофорта.

Упор на швартовах передним ходом (тяговое усилие на гак) должен был составлять приблизительно 200 тонн при 100 \% МДМ.

Форма корпуса судна проекта IBSV01, отвечающая указанным выше требованиям, создавалась на основе модельных испытаний в опытовых бассейнах (глубоководном и ледовом), проведенных Aker Arctic Technology [7] и в Крыловском государственном научном центре (КГНЦ) [8].

Общий вид модели корпуса представлен на рисунках 2 и 3. Примеры результатов моделирования - на рисунках 4-7. 
Рис. 2. Модель судна проекта IBSV01, разработанная в ледовом бассейне Aker Arctic [7]

Рис. 3. Модель судна проекта IBSV01, разработанная в КГНЦ [8]

Pис. 4. Испьтания судна проекта IBSV01 в ледовом бассейне Aker Arctic. Ледяной торос, высота 15 м. Движение носом. Вид на надводную часть ледокола [7]

Puc. 5. Испытания судна проекта IBSV01 в ледовом бассейне Aker Arctic. Ровный лед, высота 1,27 м. Движение кормой. Вид на подводную часть ледокола [7]

Согласно с результатами испытаний [7] разработанный концепт при движении носом со скоростью 2,2 узла на глубокой виде и 1,1 узла на мелководье, при движении кормой вперед - 2,6 узла и 0,8 узла соответственно. Отмечалось, что ледопроходимость на глубокой воде лучше при движении кормой вперед, а на мелководье - наоборот.

Рис. 6. Определение буксировочного сопротивления судна проекта IBSV01 в глубоководном бассейне КГНЦ. Скорость 18 узл. Вид в нос [8]

Рис. 7. Самоходные испытания судна проекта IBSV01 в глубоководном бассейне КГНЦ. Скорость 18 узл. Вид в нос и корму [8] 
Испытания в ледовой каше толщиной 7,0 м проводились только на мелководье, при этом концепт достиг скорости в 1,7 узла на переднем ходу и 4,0 узла на заднем ходу.

Кроме того, было проверены прохождение через гряды торосов, выход из ледового канала ходом вперед и задним ходом; повороты при движении ходом вперед и задним ходом; поворот в ледовом канале перемещением по схеме «звезда». Маневренные свойства обеспечивались за счет наличия и соответствующего расположения трех ВРК, при этом кормой вперед модель маневрировала лучше, чем носом.

При прохождении гряды торосов модель вела себя при движении носом вперед и кормой вперед по разному. При движении носом вперед, когда судно останавливалось, приходилось преодолевать торосы набегами. При движении кормой вперед, напротив, набеги не требовались, торосы успешно преодолевались за счет размывания винтами ВРК.

Во время модельных испытаний было установлено, что принятые обводы и пропульсия концепта IBSV01 отвечают всем эксплуатационным требованиям. Испытания не выявили каких-либо серьезных проблем с формой корпуса. Модель плавно преодолевала все препятствия во всех ледовых условиях, за исключением льда толщиной 3,0 м, что собственно и ожидалось. Также при испытаниях кормой вперед в ледовом поле толщиной 2,1 м на мелководье судно остановилось, но потом продолжило движение. Прохождение ледяной каши очень хорошо осуществлялось при движении кормой вперед за счет работы винтов ВРК (аналогично при работе через гряды торосов). Модель за счет наличия трех ВРК прекрасно маневрировала во льду.

По результатам испытаний была определена необходимая мощность пропульсии в 21,5 МВт.

При этом расположение ВРК - две в корме, одна в носу и носовое подруливающее устройство «винт в трубе», позволили также обеспечить требования PC по классу DYNPOS-2 для системы динамического позиционирования (ДП).

Система ДП обеспечила компенсацию смещений от заданного курса или в заданной точке позиционирования при следующих погодных условиях: зимой при сплоченности льда до 50 \%, летом при скорости ветра до $25 \mathrm{~m} / \mathrm{c}$, скорости течения до 1,2 м/с и высоте волн до $3 \mathrm{~m}$, что позволяет обеспечить устойчивости судна на точке во время выполнения водолазных работ, а также при работе рядом с буровыми платформами.

При этом в качестве основных средств движения и управления концепта проекта IBSV01 были выбраны две кормовые полноповоротные винто-рулевые колонки фирмы Azipod x 7500 кВт и одна носовая Azipod x 6500 кВт - см. рисунок 9.

Каждая пропульсивная установка оснащена одним четырехлопастным винтом с фиксированным шагом со съемными лопастями (на 
ВІСНИК

ОДЕСЬКОГО НАЦІОНАЛЬНОГО

МОРСЬКОГО УНІВЕРСИТЕТУ № 2 (59), 2019
HERALD

OF THE ODESSA NATIONAL

MARITIME UNIVERSITY № 2 (59), 2019

болтовых креплениях). Диаметры носовых винтов - 4000 мм, кормовых 4200 мм. Винты и втулки винтов изготовлены из нержавеющей стали.

Судно оснащено подруливающим устройством (ПУ) типа «винт в трубе» в носовой оконечности мощностью 1800 кВт с диаметром гребного винта около 2700 мм. Подруливающее устройство имеет винт фиксированного шага и оснащено частотно-регулируемой системой привода, рассчитано для непрерывной ДП работы и эксплуатации в водах со льдами.

Система ДП обеспечивает одновременное управление следующими САУС для обеспечения одного из двух заданных режимов работы:

- кормовые ВРК (один основной, один резервный);

- носовой ВРК и носовое ПУ (ПУ - основное САУС, ВРК резервное).

Как судно обеспечения, проект IBSV01 получил компоновку с открытой кормовой палубой (площадь $500 \mathrm{M}^{2}$ и допускаемая нагрузка $5 \mathrm{~T} / \mathrm{M}^{2}$ ) для размещения палубного груза и операций по буксировке. В носовой части грузовой палубы была установлена под навесом буксирная лебедка.

Жилые помещения, рубка и отделение главных дизель-генераторов были размещены в средней части.

Носовая часть судна обеспечивает прохождение судна во всех ледовых условиях в пределах установленных характеристик и ледовых подкреплений корпуса судна.

Корма судна создавалась с учетом широкого диапазона ледокольных и эскортных операций в заданном районе эксплуатации и для расчетных ледовых условий.

Схема общего расположения судна проекта IBSV01 представлена на рисунке 8 .

Рис. 8. Общее расположение ледокола мощностью $22 \mathrm{MBm}$ проекта IBSVOI

В итоге, был назначен класс Российского Морского Регистра Судоходства для концепта IBSV01 KM Icebreaker 81 AUT1-ICS FF1WS DYNPOS-2 EPP ANTI-ICE ECO SDS $<12$ Winterization(-50) Tug, который полностью отражает многофункциональность судна. таблице 1.

Главные размерения судна проекта IBSV01 представлены в

Таблица 1

Главные размерения судна проекта IBSV01

\begin{tabular}{|c|c|}
\hline \multicolumn{1}{|c|}{ Параметр } & Значение \\
\hline Длина наибольшая, м & 121,7 \\
\hline
\end{tabular}


ВІСНИК

ОДЕСЬКОГО НАЦІОНАЛЬНОГО

МОРСЬКОГО УНІВЕРСИТЕТУ

№ 2 (59), 2019
HERALD

OF THE ODESSA NATIONAL

MARITIME UNIVERSITY № 2 (59), 2019

\begin{tabular}{|l|c|}
\hline Длина наибольшая, без буксирной выемки, м & 116,5 \\
\hline Длина по КВЛ, м & 107,90 \\
\hline Ширина по КВЛ на миделе, м & 25,0 \\
\hline $\begin{array}{l}\text { Ширина по главной палубе, включая отбойные кон- } \\
\text { струкции, м }\end{array}$ & 26,0 \\
\hline Высота борта, м & 11,5 \\
\hline Осадка по КВЛ, м & 8,0 \\
\hline Осадка максимальная, м & 8,2 \\
\hline Водоизмещение при осадке по КВЛ, т & 13397 \\
\hline Водоизмещение при максимальной осадке, т & 12590 \\
\hline Дедвейт при осадке по КВЛ, т & 3774 \\
\hline Дедвейт при максимальной осадке, т & 4581 \\
\hline
\end{tabular}

Судно проекта IBSV01 имеет неограниченный район плавания, включая плавание по трассам Северного морского пути и спроектировано с учетом принципа нулевого сброса или утечки нефти при эксплуатации. Все твердые и жидкие отходы находятся на борту и утилизируются на берегу.

Для этих целей при проектировании и строительстве, кроме требований Правил РС и действующих Международных Конвенций, в полной мере были учтены требования «Международного Кодекса для судов, эксплуатирующихся в полярных водах (Полярный Кодекс)» и «Требования к конструкции, оборудованию и снабжению судов, следующих по Северному морскому пути», например, все топливные, масляные и прочие цистерны, в которых размещаются жидкости - загрязнители моря, расположены таким образом, чтобы содержащаяся в них среда не соприкасалась с наружной обшивкой.

Интересно отметить, что монтаж ВРК Azipod выполнялся не на стапельной площадке, как это реализуется традиционно, а при нахождении судна в акватории завода с помощью специального технологического понтона проекта Р05А, разработанного Морским Инженерным Бюро и специалистами Технического центра подготовки производства Выборгского судостроительного завода (см. рисунок 9).

Проект Р05А представляет собой стальной понтон П-образной формы, разделенный на четыре балластных отсека, со стапель-палубой, двумя спонсонами.

Монтаж ВРК Azipod «на плаву» позволил заводу освободить стапельную палубу полупогружной баржи «Атлант» для формирования корпуса второго судна серии проекта IBSV01.

Рис. 9. Винто-рулевая колонка фирмы Аzірод в понтоне проекта Р05А перед установкой на судне 
ВІСНИК

ОДЕСЬКОГО НАЦІОНАЛЬНОГО

МОРСЬКОГО УНІВЕРСИТЕТУ

№ 2 (59), 2019
HERALD

OF THE ODESSA NATIONAL

MARITIME UNIVERSITY № 2 (59), 2019

Максимальная скорость, достигнутая на испытаниях т/х «Андрей Вилькицкий», составляет 16,8 узла при ходе носом вперед и 15,0 узлов кормой вперед [9]. Экономический ход - 12,0 узлов. Фактический упор на швартовах передним ходом составил 210 тонн.

Маневренные характеристики судов полностью соответствуют требованиям ИМО и РС (резолюция MSC. 137(76), «Руководство по определению маневренных характеристик судов» РС, № 2-030101-007) [9] и приведены в таблице 2 .

Таблицุа 2

Маневренные характеристики судна

\begin{tabular}{|c|c|c|}
\hline Параметр & Результаты испытаний & Критерии ИМО \\
\hline \multicolumn{3}{|c|}{ Циркуляция $35^{\circ}$} \\
\hline Выдвиг & $225,3 \mathrm{M}=2,1 \mathrm{~L}$ & $4,5 \mathrm{~L}$ \\
\hline Тактический диаметр & $133,4 \mathrm{M}=1,2 \mathrm{~L}$ & $5,0 \mathrm{~L}$ \\
\hline \multicolumn{3}{|c|}{ Зиг-заг $10^{\circ} / 10^{\circ}$} \\
\hline Первый угол зарыскивания & $12,0^{\circ}$ & $12,3^{\circ}$ \\
\hline Второй угол зарыскивания & $27,9^{\circ}$ & $28,4^{\circ}$ \\
\hline \multicolumn{3}{|c|}{ Зиг-заг $20^{\circ} / 20^{\circ}$} \\
\hline Первый угол зарыскивания & 24,3 & $25^{\circ}$ \\
\hline \multicolumn{3}{|c|}{ Начальная поворотливость } \\
\hline Дистанция $10^{\circ}$ изменения курса & $140,3 \mathrm{M}=1,3 \mathrm{~L}$ & $2,5 \mathrm{~L}$ \\
\hline \multicolumn{3}{|c|}{ Тормозная характеристика } \\
\hline Тормозной путь & $400,5 \mathrm{M}=3,7 \mathrm{~L}$ & $15 L$ \\
\hline
\end{tabular}

По результатам испытаний определено, что циркуляции судна на оба борта симметричны. Судно на циркуляции всегда развернуто носом внутрь траектории на угол дрейфа. Наибольшее значение угла дрейфа (по корме) равно $67,4^{\circ}$ при перекладке ВРК $35^{\circ}$.

Падение скорости на циркуляции тем больше, чем выше начальная скорость и угол перекладки ВРК. Наибольшее падение скорости приходится на первую треть циркуляции, на последней четверти циркуляции скорость стабилизируется.

При циркуляции с набором скорости («Уход с якорной стоянки») выдвиг сокращается более чем в два раза.

Результаты испытаний маневра «прямая спираль» показали динамическую устойчивость судна.

Для предотвращения столкновения с неподвижным объектом или судном маневр изменения курса эффективнее маневра изменения скорости.

При движении задним ходом судно удерживается на прямом курсе до скорости 5 узлов; также судно выходит из циркуляции заднего хода. 
Корпус и винто-рулевой комплекс судна проекта IBSV01 спроектирован на ледовую категорию Icebreaker 8, при этом предусмотрена возможность эксплуатации судна при температурах до минус $50{ }^{\circ} \mathrm{C}$.

Остойчивость судна во всех эксплуатационных случаях нагрузки удовлетворяет требованиям «Правил», предъявляемых к судам неограниченного района плавания. В наихудшем из типовых вариантов нагрузки метацентрическая высота с учетом поправок на свободные поверхности составляет 3,21 м, угол максимума диаграммы статической остойчивости 35,5 градусов, максимальное плечо 1,27 м, угол заката 63,8 градусов, площадь ДСО до 30 градусов 0,392 мрад, критерий погоды 2.9. Масса палубного груза при этом до 350 тонн.

Посадка судна во всех типовых случаях обеспечивается с приемлемым для практики дифферентом. Осадка кормой во всех эксплуатационных случаях нагрузки обеспечивает полное погружение гребного винта (минимальная величина осадки кормой 7,86 м). Осадка носом во всех типовых случаях нагрузки с грузом обеспечивает умеренный слемминг (минимальная величина осадки 7,48 м).

Корпус, в основном, выполнен из судостроительной стали высокой прочности с пределом текучести $355 \mathrm{MПа.} \mathrm{Для} \mathrm{наружной} \mathrm{обшивки} \mathrm{в}$ районе ледового пояса и продольных ребер жесткости днища - сталь с пределом текучести 500 МПа (см. схему растяжки наружной обшивки на рисунке 10).

\section{Рис. 10. Схема растяжки наружной обшивки конщепта IBSV01}

с указанием зон со сталью с пределом текучести 500 МПа

На судне устанавливаются 8 главных водонепроницаемых поперечных переборок, разделяющих корпус на 9 непроницаемых отсеков. Требования Части «Деление на отсеки» Правил РС к посадке и остойчивости поврежденного судна выполняются при расположении бортовых и днищевых повреждений в любом месте по длине судна между соседними поперечными переборками, а также при ледовых повреждениях

Автономность с учетом запасов дизельного топлива, а также объемов для хранения жидких и твердых отходов при различных условиях навигации составляет не менее 30 суток.

Автономность с учетом запасов продуктов питания и пресной воды (с возможностью пополнения запасов с помощью опреснителя испарительного типа) составляет не менее 40 суток.

Судно подготовлено к эксплуатации в зимних условиях, чтобы обеспечить требуемые рабочие характеристики в условиях низких температур окружающей среды в порту и прилегающих районах Обской губы 
ВІСНИК

ОДЕСЬКОГО НАЦІОНАЛЬНОГО

МОРСЬКОГО УНІВЕРСИТЕТУ

№ 2 (59), 2019
HERALD

OF THE ODESSA NATIONAL

MARITIME UNIVERSITY № 2 (59), 2019

и в соответствии с требованиями Регистра судоходства по классам ANTI-ICE и Winterization $\left(-50^{\circ} \mathrm{C}\right)$.

Энергетическая установка состоит из четырех главных дизельгенераторов и одного стояночного генератора. Дополнительно предусмотрен один аварийный дизель-генератор.

Главная энергетическая установка - дизель-электрическая, состоящая из четырёх главных дизель-генераторов (ГДГ) переменного тока 6600 В, 50 Гц электрической мощностью - 2 х 9900 кВА (каждый) и 2 х 4950 кВА (каждый).

Жилые и служебные помещения расположены в надстройке над главной палубой (см. рисунок 11). Рулевая рубка выполнена с круговым обзором (см. рисунок 12).

\section{Рис. 11. Надстройка судна и рулевая рубка}

Судно имеет помещения для размещения команды из 21 человека, лоцмана и представителя судовладельца, а также запасные каюты для 12 сверхштатных работников, включая обслуживающий персонал терминала.

Все каюты оборудованы индивидуальными санузлами.

Размещение спасённых людей предусматривается в кают-компании, салоне для отдыха, столовой экипажа, а также на резервных спальных местах в каютах. Также имеется госпиталь на два койко-места.

\section{Рис. 12. Внутренний вид рулевой рубки}

Общее количество мест на судне рассчитано на 35 человек (см. таблицу 3). Предусмотрены индивидуальные и коллективные спасательные средства.

Таблича 3

Каюты для экипажа и сверхитатных работников

\begin{tabular}{|l|c|c|}
\hline & Каюты & Койки \\
\hline Капитанские каюты со спальней & 2 & 2 \\
\hline $\begin{array}{l}\text { Офицерские каюты } \\
\text { (включая каюту Судовладельца) }\end{array}$ & 4 & 4 \\
\hline Каюта для лоцмана & 1 & 1 \\
\hline Экипаж (команда) & 16 & 16 \\
\hline Сверхштатные работники & 6 & 12 \\
\hline Итого & 29 & 35 \\
\hline
\end{tabular}


ВІСНИК

ОДЕСЬКОГО НАЦІОНАЛЬНОГО

МОРСЬКОГО УНІВЕРСИТЕТУ № 2 (59), 2019
HERALD

OF THE ODESSA NATIONAL

MARITIME UNIVERSITY № 2 (59), 2019

Для улучшения параметров обитаемости на судне предусмотрена система успокоения бортовой качки. Одна U-образная цистерна снижения качки установлена в средней части судна. Стальные конструкции внутри цистерн спроектированы таким образом, чтобы свести к минимуму турбулентность внутри цистерны. Величина расхода воды может регулироваться путем изменения расхода воздуха между частями цистерны.

Для оперативной доставки аварийной партии на терпящее бедствие судно предусмотрен вспомогательный катер вместимостью 6 человек (см. рисунок 13). Эксплуатация катера возможна при волнении до 6 баллов. Катер оборудован гаком быстроотдающегося типа для сцепления с судовым краном. Спуск/подъем без людей осуществляется палубным краном грузоподъемностью 26 т.

\section{Рис. 13. Вспомогательный катер}

Длина вспомогательного катера приблизительно 6,5 м, грузоподъёмность - 1000 кг. Обеспечивается возможность эксплуатации катера в присутствии небольших плавучих льдин. Также предусмотрена возможность использовать вспомогательный катер для проведения работ для развертывания боновых заграждений.

Две самовосстанавливающиеся спасательные шлюпки закрытого типа в защищенном месте, сертифицированные SOLAS для танкеров, рассчитанные на 35 человек каждая и подготовленные надлежащим образом к зимней эксплуатации (см. рисунок 14). Одна спасательная шлюпка также соответствует требованиям к дежурной шлюпке вместимостью шесть человек.

Предусмотрены три спасательных сбрасываемых плота на двенадцать человек каждый, на каждом борту судна, все в жестких водонепроницаемых стеклопластиковых рифленых контейнерах. Плоты установлены на стальных стеллажах. Спасательные плоты оборудованы системой обогрева, чтобы обеспечить надёжный обогрев в арктических условиях.

\section{Рис. 14. Спасательная шлюпка}

Кроме коллективных и индивидуальных спасательных средств на судне предусмотрены специальные контейнеры на салазках с комплектами спасательного оборудования и снабжения для выживания на льду (см. рисунок 15). 
ВІСНИК

ОДЕСЬКОГО НАЦІОНАЛЬНОГО

МОРСЬКОГО УНІВЕРСИТЕТУ № 2 (59), 2019
HERALD

OF THE ODESSA NATIONAL

MARITIME UNIVERSITY № 2 (59), 2019

Рис. 15. Контейнеры с комплектами для выюживания на льду

Для экстренной эвакуации пострадавших, а также для доставки на борт судна дополнительного персонала (бригада медиков, аварийная партия и т.п.) судно оснащено посадочной вертолетной платформой см. рисунок 16, расположенной впереди надстройки судна для вертолета типа МИ-8 (с максимальным весом 14 тонн и диаметром винта 25,35 м).

\section{Рис. 16. Вертолетная площадка судна}

Поверхность вертолетной платформы имеет плоскую часть шириной 14,6 м относительно ДП судна и погибь к бортам остальной части палубы равной 55 мм, также седловатость с уклоном в корму около 1:100 (250 мм) для обеспечения стока воды. Она изготовлена из листовой стали, имеет два независимых выхода для людей, расположенных по бортам в кормовой части площадки, по правому и левому бортам соответственно, и равноудаленных от места посадки вертолета. Перед выходами на вертолетную посадочную площадку установлены световые табло о запрете/ разрешении выхода.

По периметру вертолетной посадочной площадки установлено леерное ограждение заваливающегося типа, которое в заваленном положении не выступает за габарит палубы.

Вертолетная палуба по всему периметру имеет сплошной ограждающий комингс высотой 50 мм, предотвращающий распространение утечки топлива, а также для минимизации риска соскальзывания персонала.

Схема зоны посадки вертолета типа МИ-8 на вертодром ледокола проекта IBSV01 показана на рисунках 16-17.

Рис. 17. Схема зоны посадки вертолета типа МИ-8 на вертодром ледокола проекта IBSV01

В мае 2019 года компания «Газмпром нефть» отработала посадку вертолета МИ-8МТВ на ледоколы проекта IBSV01 [10]. Отмечалось, что такой тип вертолета «можно будет использовать в период, когда осложнится навигация - например, уже в июле лед начнет двигаться, но МИ-8МТВ сможет доставить персонал и оборудование с берега на борт».

Одна двухбарабанная электрическая буксирная лебедка, предназначенная для буксировки аварийных судов, установлена в кормовой части палубы под навесом. Требования, предъявляемые к буксирным барабанам, представлены в таблице 4.

Таблица 4 
ВІСНИК

ОДЕСЬКОГО НАЦІОНАЛЬНОГО

МОРСЬКОГО УНІВЕРСИТЕТУ

№ 2 (59), 2019
HERALD

OF THE ODESSA NATIONAL

MARITIME UNIVERSITY № 2 (59), 2019

Требования, предъявляемые к буксирным барабанам

\begin{tabular}{|l|c|}
\hline \multicolumn{1}{|c|}{ Параметр } & Значение \\
\hline $\begin{array}{l}\text { Держащее усилие ленточного тормоза (первый } \\
\text { слой - статический), регулируемое }\end{array}$ & 3300 кН \\
\hline Тяговое усилие на канате (рабочий слой) & 1000 кН (около 2 м/мин.) \\
\hline Скорость подъема каната без груза (первый слой) & около 30 м/мин. \\
\hline
\end{tabular}

Полезная тяга и тяга на гаке ледокола на швартовном режиме составила 2183 кН. Тяга на гаке ледокола на скорости буксировки 5-6 узлов $1780-1680$ кН.

Погрузка на судно контейнеров с оборудованием и снабжением и выполнение прочих грузоподъёмных операций обеспечивается одним электрогидравлическим грузовым консольным краном (см. рисунок 18) грузоподъемностью 26 т с вылетом стрелы 27 м в кормовой части главной палубы с правого борта.

Рис. 18. Грузовой кран в проиессе строительства судна

Предусмотрена возможность спуска и подъема краном ковшового нефтесборщика (скиммера) и грейфера.

Грузовой кран способен работать на полной грузоподъемности в условиях открытого моря при силе ветра не более 6 баллов (средняя скорость ветра 11 м/с, скорость ветра в порывах 25 м/с), на волнении силой до 5 баллов (высота волны $3 \%$ обеспеченности 3,5 м). Остойчивость судна при работе краном удовлетворяет требованиям «Правил» Регистра, предъявляемых к крановым судам.

Подача воды на аварийный объект осуществляется через 4 лафетных ствола с подачей $2500 \mathrm{~m}^{3} /$ и и длиной струи $150 \mathrm{м}$, установленные на платформе над рулевой рубкой (см. рисунок 19). При одновременной работе всех лафетных стволов с максимальным расходом в направлении, соответствующем минимальной остойчивости судна, образующийся статический угол крена не превышает $1^{\circ}$ при допускаемых $5^{\circ}$.

\section{Рис. 19. Лафетные стволы на платформе}

Предусмотрена подача пены для двух пожарных гидромониторов вертолётной площадки (см. рисунок 20).

Отдельная система пенного пожаротушения предусмотрена для вертолетной площадки судна.

Для подачи воды в специальную систему пожаротушения на судне установлены 4 насоса, производительностью 2900 м³/ч каждый, с приво- 
дом от главных дизель-генераторов. Для защиты судна от теплового воздействия горящего объекта предусматривается система водяных завес.

Два пожарных/палубных насоса установлены на борту судна для обслуживания пожарной магистрали.

\section{Рис. 20. Пожарный лафет вертолётной площадки}

Количество и расположение пожарных гидрантов, включая пожарные рукава, определено в соответствии с Правилами. На открытой палубе установлено достаточное количество пожарных гидрантов для обмывания палубы.

Водяная система пожаротушения оборудована обогревателем с мощностью, позволяющей нагревать поток воды в одном пожарном шланге до $40{ }^{\circ} \mathrm{C}$ для удаления льда и снега с чувствительного оборудования.

Для тушения пожара на самом судне установлено 2 пожарных насоса производительностью 80 м³/ч каждый и один аварийный пожарный насос производительностью $60 \mathrm{~m}^{3} / 4$.

Местная система пожаротушения водяным туманом с насосной установкой и сопутствующей распределительной трубной обвязкой установлена для главных дизель-генераторов, стояночного дизель-генератора, сепараторов топлива и смазочного масла, котлов на дизельном топливе, инсинератора и прочего оборудования.

Стационарная система углекислотного пожаротушения высокого давления с баллонами с $\mathrm{CO} 2$, клапанами и устройствами выпуска предусмотрена для помещений машинного отделения, включая помещение аварийного дизель-генератора и помещения главных механизмов, помещений с электроаппаратурой, требуемой правилами, хранилищем лакокрасочных материалов.

Дополнительный портативный насос льяльных вод предусмотрен на борту судна в соответствии с условным обозначением класса FF1WS для обеспечения возможности слива содержимого затопленных отсеков судов, терпящих бедствие.

Водолазное оборудование для двух человек предусмотрено для работы водолазов на глубине моря до 12 м.

Спуск водолазов при отсутствии льда на поверхности моря осуществляется по водолазному трапу с борта судна.

Одной из основных функций судов проекта IBSV01 является ликвидация аварийных разливов нефти и нефтепродуктов.

Судно оснащено подъемным оборудованием для выполнения работ с оборудованием по сбору разливов нефти (OSR) при реагировании на разливы нефти с температурой вспышки свыше $60{ }^{\circ} \mathrm{C}$. 
Судно имеет возможность работать с нефтяными бонами вместе с другими судами, а также спускать на воду с помощью палубного крана катера-нефтесборщика. В зимних условиях специальный ковшовый нефтесборщик может быть установлен на палубный кран. Оборудование для сбора разливов нефти устанавливаются на главной палубе судна в четыpex 20-футовых контейнерах. Собранная нефть хранится в специальных нефтяных резервуарах для собранной нефти, в которые она подается через люки на главной палубе. Отвод собранной нефти осуществляется с помощью погружных насосов через люки на главной палубе. Также предусмотрен люк для погрузки загрязненных плавучих льдин в обогреваемые резервуары собранной нефти, в которых они будут таять. Цистерны собранной нефти обеспечены патрубками для промывки паром.

Для этих целей на судне имеются цистерны для сбора нефти, а также установлено следующее оборудование:

- вьюшки для тяжелых бонов;

- катушка с тяжелыми нефтеограждающими бонами длиной 250 м;

- катушка с тяжелыми нефтеограждающими бонами длиной 200 м;

- прочее вспомогательное оборудование для сбора разливов нефти.

Для привода оборудования ЛАРН предусмотрен дизель-гидравлический агрегат. Также на палубе судна размещается один катербонопостановщик. Судно оснащено оборудованием для распыления дисперсантов по обоим бортам судна.

Как сообщала пресс-служба «Газпромнефть-Ямала», ледоколы мощностью 22 МВт класса Icebreaker 8 проекта IBSV01 «Андрей Вилькицкий» и «Александр Санников» в июле 2019 года приняли участие в учениях по ликвидации условного разлива нефти в Обской губе (см. рисунок 21).

\section{Рис. 21. На учениях по ликвидачии аварийного разлива нефти [10]}

По легенде учений, судам предстояло ликвидировать последствия условной внештатной ситуации, которая произошла в акватории Обской губы в районе нефтеналивного терминала «Ворота Арктики» Новопортовского месторождения после столкновения танкера с неопознанным объектом. Экипажи оперативно развернули современное аварийноспасательное оборудование, с помощью маневренных катеров произвели установку заградительных бонов и скиммера.

Каждый ледокол оснащен специальными емкостями объемом 1300 куб. м, что позволяет длительное время хранить собранные с водной поверхности нефтепродукты. Это необходимо для работы в арктическом 
ВІСНИК

ОДЕСЬКОГО НАЦІОНАЛЬНОГО

МОРСЬКОГО УНІВЕРСИТЕТУ

№ 2 (59), 2019
HERALD

OF THE ODESSA NATIONAL

MARITIME UNIVERSITY № 2 (59), 2019

регионе, где в межсезонье связь с берегом не всегда регулярная из-за сложной ледовой обстановки. Морская стихия также вносила свои корректировки в планы служб, на всем протяжении учений производился мониторинг высоты волн, скорости ветра и температуры воздуха.

Масштабные морские учения вблизи объектов Новопортовского нефтепромысла проводятся два раза в год. Готовность всех служб проверяется зимой и летом, что позволяет отработать слаженность действий в разных погодных условиях.

Летний период 2019 года для ледоколов - первый сезон совместного дежурства, поэтому до сентября для экипажей сформирован плотный график еженедельных тренировок, которые позволят судам лучше освоиться в Арктике. По итогам учений «Газпромнефть-Шиппинг» получил разрешение на проведение аварийно-спасательных работ по ликвидации разливов нефтепродуктов, а также поисково-спасательных операций. Учения прошли успешно, учебные цели были достигнуты, поставленные задачи выполнены [10].

Заключение. Ходовые испытания, натурные испытания во льду и эксплуатация судов типа IBSV01 показали, что суда в полной степени удовлетворяют требованиям Заказчика как по ходовым, так и по функциональным качествам, показывают высокую маневренность при работе в ледовых условиях (см. рисунки 22-24).

Puс. 22. Вид с носа судна проекта IBSV01 [11]

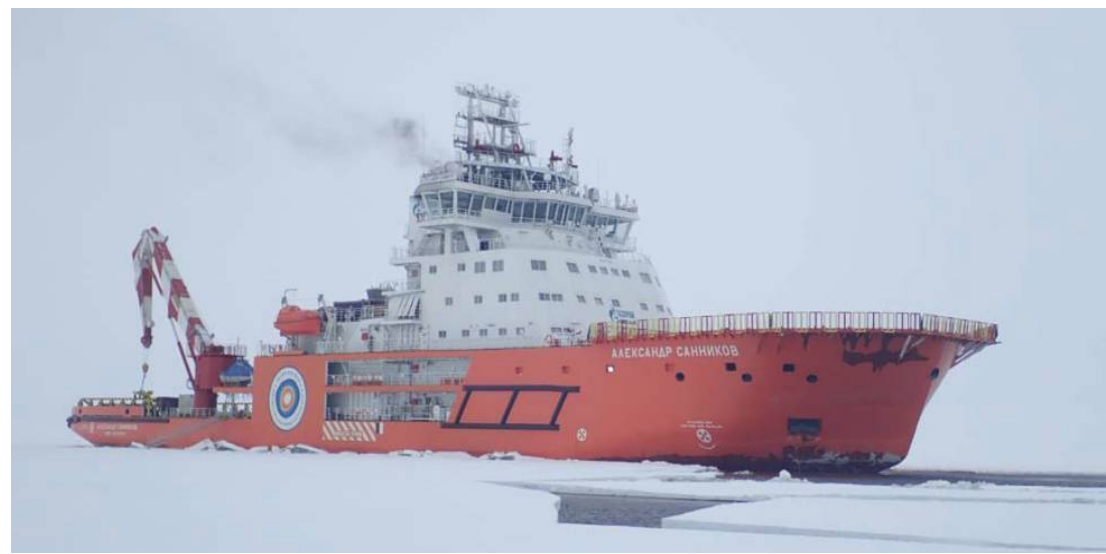

Рис. 23. Судно проекта IBSV01 во время натурных ледовых испытаний [10]

Рис. 24. Общиий вид судна проекта IBSV01 [11] 
Как сообщала пресс-служба «Газпромнефть-Ямала» [10], во время натурных испытаний в апреле 2019 года в Обской губе ледокол - судно обеспечения проекта IBSV01 «Александр Санников» показал высокую маневренность при работе в ледовых условиях. В сплошном льду толщиной 123 см со снежным покровом толщиной 39 см циркуляция на переднем ходу выполнялась с радиусом 147 м. Время от начала маневра до скола ледяного поля составило 4 минуты 50 секунд. На заднем ходу маневр был выполнен с радиусом 102 м во льду средней толщины $121 \mathrm{~cm}$ со снежным покровом 44 см. Время от начала маневра до скола ледяного поля составило 4 минуты 40 секунд.

Разворот на $180^{\circ}$ способом «звезда» выполнялся при движении кормой вперед в собственном канале - время маневра составило 129 секунд.

В старом смороженном переметенном снегом набитом канале при движении кормой вперед при средней толщиной смерзшегося льда 238 см с пиковыми значениями до 415 см обеспечивалась средняя скорость хода 2,5 узла. В таком же старом канале при движении носом вперед при средней толщине смерзшегося льда 188 см с пиковыми значениями до 244 см средняя скорость составила 3,1 узла.

На переднем и на заднем ходу судно преодолело торосистую гряду толщиной около 3 м со скоростью не менее 3 узлов. таблице 5.

Обобщенные результаты проверки ледопроходимости указаны в

Таблица 5

Значения достижимых скоростей

при фактических характеристиках ледяного покрова

\begin{tabular}{|c|c|c|c|}
\hline \multirow[b]{2}{*}{$\begin{array}{c}\text { Режим } \\
\text { движения }\end{array}$} & \multirow[b]{2}{*}{$\begin{array}{l}\text { Скорость } \\
\text { судна, узлы }\end{array}$} & \multicolumn{2}{|c|}{ Характеристика ледяного покрова } \\
\hline & & $\begin{array}{c}\text { эквивалентная } \\
\text { толщина льда, см }\end{array}$ & $\begin{array}{c}\text { прочность льда, } \\
\text { кПа }\end{array}$ \\
\hline Носом вперед & 6,42 & 135 & 725 \\
\hline Кормой вперед & 6,13 & 135 & 755 \\
\hline
\end{tabular}

Источник: ААНИИ

В ходе серии натурных экспериментов, проведенных в Обской губе, главная характеристика судна проекта IBSV01 подтвердилась - при конструктивной осадке 8,2 м и номинальной мощности на валах электродвигателей полноповоротных ВРК в ровном сплошном льду толщиной 
ВІСНИК

ОДЕСЬКОГО НАЦІОНАЛЬНОГО

МОРСЬКОГО УНІВЕРСИТЕТУ

№ 2 (59), 2019
HERALD

OF THE ODESSA NATIONAL

MARITIME UNIVERSITY № 2 (59), 2019

200 см и прочностью 700 кПа с толщиной снежного покрова на льду 30 см ледокол обеспечивает скорость в 2,0 узла на переднем и заднем ходах.

Как отметил генеральный директор «Газпромнефть-Ямал» Алексей Овечкин, «ледоколы ... в полной мере готовы к суровым зимам Крайнего Севера, где каждый день им приходится решать сложные задачи» [10].

В таблице 6 приведены этапы строительства судов проекта IBSV01.

Таблица 6

Этапы строительства судов проекта IBSV01

\begin{tabular}{|l|l|c|c|c|}
\hline \multicolumn{1}{|c|}{ Название } & $\begin{array}{c}\text { Верфь, } \\
\text { строительный номер }\end{array}$ & $\begin{array}{c}\text { Дата } \\
\text { закладки }\end{array}$ & $\begin{array}{c}\text { Дата } \\
\text { спуска }\end{array}$ & $\begin{array}{c}\text { Дата } \\
\text { сдачи }\end{array}$ \\
\hline Александр Санников & Выборгский С3, 233 & 03.11 .15 & 24.11 .16 & 30.07 .18 \\
\hline Андрей Вилькицкий & Выборгский С3, 234 & 14.12 .15 & 05.07 .17 & 17.12 .18 \\
\hline
\end{tabular}

\section{СПИСОК ЛІТЕРАТУРИ}

1. Егоров Г.В., Штрамбранд В.И. Многофункииональные ледоколь и ледоколь-спасатели нового поколения // Вісник OHМУ. Oдеса: ОНМУ, 2012. Bun. 34(1). C. 130-150.

2. Оиенка влияния подходного канала к порту Сабетта на изменение гидрологических условий Обской губы с помощьью численного моделирования / Н.А. Дианский, В.В. Фомин, В.М. Грузинов, И.М. Кабатченко, Г.И. Литвиненко // Арктика: экология и экономика. № 3 (19), 2015. С. 18-29.

3. Практические рекомендачии капитанов СКФ по управлению судами в ледовых условиях. М.: Паульсен, 2019. 296 с.

4. Спирин А.М., Чачин Д.А., Смирнов А.А. Круглогодичная навигачия на порт Сабетта // Арктика: экология и экономика. № 3 (19). 2015. С. 88-95.

5. Egorov G.V. Investigation of «line-up» of multipurpose salvage vessels for work in Russian adjacent seas // Proc. of Thirteenth Intern. Conf. on marine sciences and technologies (Black Sea' 2016). Varna (Bulgaria). 2016. 116-126 p.

6. Egorov G.V., Nilva A.E., Davydov I.F. Principles of Creation of New Generation of Russian Multipurpose Rescue Vessels for Ice Conditions // Proc. of the 11th International Symposium on Practical Design of Ships and Other Floating Structures (PRADS 2010). Rio de Janeiro, Brazil. 2010. Vol. 1. P. 569-578. 
ВІСНИК

ОДЕСЬКОГО НАЦІОНАЛЬНОГО

МОРСЬКОГО УНІВЕРСИТЕТУ

№ 2 (59), 2019
HERALD

OF THE ODESSA NATIONAL

MARITIME UNIVERSITY

7. Aker Arctic 27384-101-421 Rev A. Model test report - open water for icebreaking support vessel Aker ARC 130A. Aker Arctic. 2015. 245 p.

8. Aker Arctic 27384-101-430 Rev A. Ice model tests of icebreaking support vessel Aker ARC 130A (with Appendixes). Aker Arctic, 2015. $45 \mathrm{p}$.

9. IBSV01-109-016. Журнал маневренных элементов. СПб.: Морское инженерное бюро-СПб., 2018. 52 c.

10. Сайт ПАО «Газпром-нефть». URL: https://marinebunker. gazprom-neft.ru.

11. Сайт ПАО «Выборгский судостроительный завод». URL: http://vyborgshipyard.ru/ru.

\section{REFERENCE}

1. Egorov G.V., Shtrambrandt V.I. (2012). Mnogofunktsionalnyie ledokoly i ledokoly-spasateli novogo pokoleniya [Multifunctional icebreakers and icebreakers-salvage vessels of new generation]. Visnuk ONMU (Reporter of Odessa National Maritime University), 1 (34), 130-150 [in Russian].

2. Dianskiy N.A., Fomin V.V., Gruzinov V.M., Kabatchenko I.M., Litvinenko G.I. (2015). Otsenka vliyaniya podhodnogo kanala k portu Sabetta na izmenenie gidrologicheskikh usloviy Obskoy guby s pomoschyu chislennogo modelirovaniya [Estimation of influence of the approach channel to the port of Sabetta on change of hydrological conditions of the Gulf of Ob using numerical modeling]. Arktika: ecologiya i economika (Arctic: ecology and economy), 3 (19), 18-29 [in Russian].

3. Sovcomflot (2019). Prakticheskie rekomendatsii kapitanov SKF po upravleniyu sudami $v$ ledovykh usloviyakh [SCF masters practical recommendations of vessels handling in ice conditions]. Paulsen (Paulsen). Moscow, 296 pages [in Russian].

4. Spirin A.M., Chachin D.A., Smirnov A.A. (2015). Kruglogodichnaya navigatsiya na port Sabetta [Sabetta port all-year navigation]. Arktika: ecologiya i economika (Arctic: ecology and economy), 3 (19), 88-95 [in Russian].

5. Egorov G.V. (2016). Investigation of «line-up» of multipurpose salvage vessels for work in Russian adjacent seas // Proc. of Thirteenth Intern. Conf. on marine sciences and technologies (Black Sea' 2016). Varna (Bulgaria), 116-126.

6. Egorov G.V., Nilva A.E., Davydov I.F. (2010). Principles of Creation of New Generation of Russian Multipurpose Rescue Vessels for Ice Conditions // Proc. of the 11th International Symposium on 
ВІСНИК

ОДЕСЬКОГО НАЦІОНАЛЬНОГО

МОРСЬКОГО УНІВЕРСИТЕТУ

№ 2 (59), 2019
HERALD

OF THE ODESSA NATIONAL

MARITIME UNIVERSITY

№ 2 (59), 2019

Practical Design of Ships and Other Floating Structures (PRADS 2010). Rio de Janeiro (Brazil), Vol. 1, 569-578.

7. Aker Arctic (2015). Aker Arctic 27384-101-421 Rev A. Model test report - open water for icebreaking support vessel Aker ARC $130 A, 245 p$.

8. Aker Arctic (2015). Aker Arctic 27384-101-430 Rev A. Ice model tests of icebreaking support vessel Aker ARC 130A (with Appendixes), $45 \mathrm{p}$.

9. Marine Engineering Bureau (2018). IBSV01-109-016. Zhurnal manevrennykh elementov (Maneuvering data log book). St. Petersburg, $52 \mathrm{p}$.

10. «Gazprom-neft» company website. URL: https://marinebunker. gazprom-neft.ru (access date 18.10.2019).

11. "Vyborg shipbuilding yard» company website. URL: http:// vyborgshipyard.ru/ru (access date 18.10.2019).

Стаття надійшла до редакиії 21.10.2019

\section{Рецензенти:}

доктор технічних наук, професор, завідувач кафедри «Теоретична та прикладна механіка» Одеського національного морського університету А.В. Гришин

доктор технічних наук, професор, завідувач кафедри «Машинознавство» Одеського національного морського університету А.В. Конопльов 